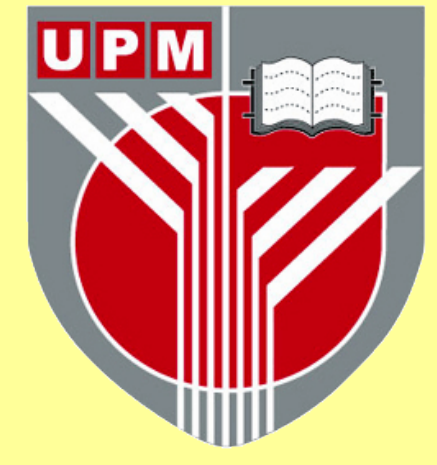

UNIVERSITI PUTRA MALAYSIA

NLFXLMS AND THF-NLFXLMS ALGORITHMS FOR WIENERHAMMERSTEIN

NONLINEAR ACTIVE NOISE CONTROL

RADIK SRAZHIDINOV

FK 201664 


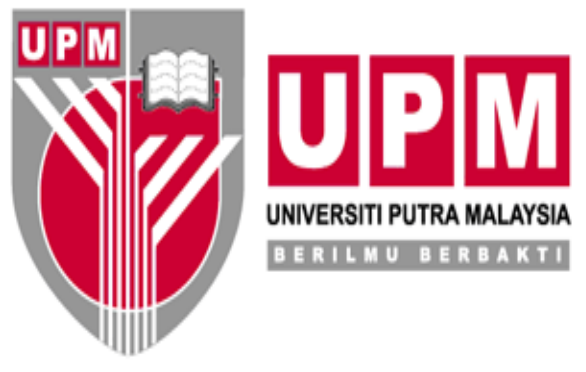

NLFXLMS AND THF-NLFXLMS ALGORITHMS FOR WIENERHAMMERSTEIN NONLINEAR ACTIVE NOISE CONTROL

By

RADIK SRAZHIDINOV

Thesis Submitted to the School of Graduate Studies, Universiti Putra Malaysia, in Fulfillment of the Requirements for the Degree of Master of Science 


\section{COPYRIGHT}

All material contained within the thesis, including without limitation text, logos, icons, photographs and all other artwork, is copyright material of Universiti Putra Malaysia unless otherwise stated. Use may be made of any material contained within the thesis for non-commercial purposes from the copyright holder. Commercial use of material may only be made with the express, prior, written permission of Universiti Putra Malaysia.

Copyright (C) Universiti Putra Malaysia 


\section{DEDICATION}

I dedicate this thesis to all Kyzylkia "Sebat" high school teachers.

Education is not a business; it is one of the human's wings. 
Abstract of thesis presented to the Senate of Universiti Putra Malaysia in fulfillment of the requirement for the Degree of Master of Science

\title{
NLFXLMS AND THF-NLFXLMS ALGORITHMS FOR WIENER- HAMMERSTEIN NONLINEAR ACTIVE NOISE CONTROL
}

\begin{abstract}
By
RADIK SRAZHIDINOV

October 2016

Chairman : Associate Professor Raja Mohd Kamil b. Raja Ahmad, PhD

Faculty : Engineering

Filtered-X least mean square (FXLMS) control algorithm is a conventional algorithm employed to cancel the noise in linear environment. However, in practical applications nonlinearities may present. These nonlinearities are usually associated with the secondary path components, such as amplifiers and loudspeakers. Block oriented method is used to represent the linear and nonlinear components in the secondary path. Usually, linear components are represented by finite impulse response (FIR) filters and nonlinear component with saturation nonlinearity scaled error function (SEF). Nonlinear FXLMS (NLFXLMS) control algorithm based on SEF has been previously developed to cancel the noise in environment with external factors that can cause nonlinearity. The major drawback of using SEF based NLFXLMS (SEF-NLFXLMS) is that the degree of nonlinearity must be known in advance for good control performance. In recent works, it was shown that the SEF can be approximated using tangential hyperbolic function (THF) for Hammerstein and Wiener NLFXLMS algorithms, such that the degree of nonlinearity can be estimated using modelling approach. The THF-NLFXLMS method is extended here for Wiener-Hammerstein model. Using this method, the need for the knowledge of the degree of nonlinearity in advance can be avoided. The proposed algorithm models the Wiener-Hammerstein linear and nonlinear components in the secondary path and applies the estimated degree of nonlinearity of the nonlinear secondary path in the control algorithm design.
\end{abstract}

In previous works, SEF-NLFXLMS and THF-NLFXLMS algorithms for Hammerstein and Wiener structures were developed where the acoustic path is assumed to be a unit gain. However, this assumption may lead to inaccurate secondary path model. In this work, the modelling of acoustic path using FIR filters is incorporated for both algorithms for Wiener-Hammerstein structure. The development of these algorithms becomes the first and second objectives of this research. It is hypothesised that incorporating the acoustic path model would improve the modelling of the secondary path and subsequently improves the level of noise cancellation.

The proposed SEF-NLFXLMS and THF-NLFXLMS algorithms are compared with the conventional FXLMS and $2^{\text {nd }}$ order Volterra FXLMS algorithms (which is 
determined to be of comparable computational complexity with the THF-NLFXLMS). The simulation results show that the Wiener-Hammerstein THF-NLFXLMS has close performance with the SEF-NLFXLMS. It outperforms the FXLMS by $2.5 \mathrm{~dB}$ and $4 \mathrm{~dB}$ and $2^{\text {nd }}$ order Volterra FXLMS by $3.5 \mathrm{~dB}$ and $4.5 \mathrm{~dB}$ for low and medium degrees of nonlinearity, respectively. In addition, Wiener-Hammerstein THF-NLFXLMS shows better performance compared to Wiener THF-NLFXLMS algorithm. 
Abstrak tesis yang dikemukakan kepada Senat Universiti Putra Malaysia sebagai memenuhi keperluan untuk Ijazah Master Sains

\title{
ALGORITMA NLFXLMS DAN ALGORITMA THF-NLFXLMS UNTUK KAWALAN AKTIF BUNYI TAK LELURUS WIENER-HAMMERSTEIN
}

\author{
Oleh \\ RADIK SRAZHIDINOV \\ Oktober 2016

\begin{abstract}
Pengerusi : Profesor Madya Raja Mohd Kamil b. Raja Ahmad, PhD Fakulti : Kejuruteraan
\end{abstract}

\begin{abstract}
Algoritma kawalan tapisan-X min kuasa dua terkecil (FXLMS) adalah algoritma konvensional yang digunakan untuk memansuhkan bunyi dalam persekitaran lelurus. Walau bagaimanapun, dalam aplikasi yang praktikal, faktor ketaklelurusan barangkali wujud. Faktor ketaklelurusan selalunya dikaitkan dengan komponen-komponen dalam laluan sekunder, seperti amplifier dan pembesar suara. Kaedah blok terhala digunakan untuk mewakili komponen lelurus dan tak lelurus dalam laluan sekunder. Biasanya, komponen lelurus diwakili oleh penapis sambutan dedenyut terhingga (FIR) manakala komponen tak lelurus yang mempunyai ketepuan ketaklelurusan diwakili oleh fungsi ralat berskala (SEF). Algoritma kawalan FXLMS tak lelurus (NLFXLMS) berdasarkan $S E F$ telah dibangunkan sebelum ini untuk memansuhkan bunyi dalam persekitaran tak lelurus. Kelemahan utama menggunakan SEF dalam NLFXLMS adalah tahap ketaklelurusan yang perlu diketahui terlebih dahulu bagi mendapatkan kawalan prestasi yang baik. Kajian terkini telah menunjukkan bahawa SEF boleh dianggarkan menggunakan fungsi tangen hiperbolik (THF) untuk algoritma NLFXLMS Hammerstein dan Wiener, yang mana tahap ketaklelurusan boleh dianggarkan menggunakan pendekatan pemodelan. Kaedah THF-NLFXLMS dilanjutkan di sini untuk model Wiener-Hammerstein. Dengan menggunakan kaedah ini, tahap ketaklelurusan tidak perlu diketahui terlebih dahulu. Algoritma yang dicadangkan untuk memodelkan komponen lelurus dan taklelurus Wiener-Hammerstein dalam laluan sekunder dan mengaplikasikan penganggaran dalam mengenal pasti tahapan ketaklelurusan laluan sekunder dalam rekabentuk algoritma kawalan.
\end{abstract}

Dalam kajian yang lalu, algoritma SEF-NFXLMS dan THF-NLFXLMS untuk struktur Hammerstein dan Weiner telah dibangunkan yang mana gandaan laluan akustik dianggap sebagai satu. Tetapi anggapan berkenaan boleh menyebabkan model laluan sekunder tidak tepat. Dalam kajian ini, kaedah permodelan laluan akustik menggunakan FIR telah menggabungkan struktur algoritma Wiener-Hammerstein. Usaha membangunkan algoritma ini merupakan objektif pertama dan kedua kajian ini. Secara hipotesis, menggabungkan model laluan akustik akan mengelokkan model untuk laluan sekunder seterusnya memperbaiki tahap pemansuhan bunyi. 
Algoritma THF-NLFXLMS yang dicadangkan telah dibandingkan dengan beberapa penanda aras iaitu algoritma SEF-NLFXLMS, algoritma FXLMS konvensional, dan algoritma tahap kedua Volterra FXLMS (yang mempunyai tahap kerumitan pengiraan yang standing dengan THF-NLFXLMS). Keputusan simulasi menunjukkan bahawa Wiener-Hammerstein THF-NLFXLMS mempunyai prestasi yang hampir sama dengan algoritma SEF-NLFXLMS. THF-NLFXLMS melebihi prestasi algoritma FXLMS dengan $2.5 \mathrm{~dB}$ dan $4 \mathrm{~dB}$ manakala melebihi prestasi algoritma Volterra FXLMS tahap kedua dengan $3.5 \mathrm{~dB}$ dan $4.5 \mathrm{~dB}$ bagi tahap ketaklelurusan rendah dan sederhana masing-masing. Selain itu, Wiener-Hammerstein THF-NLFXLMS telah menunjukkan prestasi yang lebih baik berbanding algoritma Wiener THF-NLFXLMS. 


\section{ACKNOWLEDGEMENTS}

I thank all who in one way or another contributed in the completion of this thesis. First, I give thanks to God for protection and ability to do work.

I would like to express my special appreciation and thanks to my supervisor Ir. Dr. Raja Mohd Kamil bin Raja Ahmad, you have been a tremendous mentor for me. I would like to thank you for encouraging my research and for allowing me to grow as a research scientist. Your advice on both research as well as on my career have been priceless. I would like to thank my co-supervisor, Assoc. Prof. Dr. Samsul Bahari Md Noor for the patient guidance, encouragement and advices. I also would like to thank all staff members of the Electrical and Electronics Engineering Department at Universiti Putra Malaysia.

A special thanks to my family. Words cannot express how grateful I am to my father - Zhusup, mother - Zharkynay, brothers - Nusultan and Maksat, sisters - Aynuru and Adelina, and my fiancée Eliza and daughter Kamila for all of the sacrifices that you've made on my behalf. Your prayer for me was what sustained me thus far. I would also like to thank all of my friends who supported me in writing and incited me to strive towards my goal. 
I certify that a Thesis Examination Committee has met on 6 October 2016 to conduct the final examination of Radik Srazhidinov on his thesis entitled "NLFXLMS and THF-NLFXLMS Algorithms for Wiener-Hammerstein Nonlinear Active Noise Control" in accordance with the Universities and University Colleges Act 1971 and the Constitution of the Universiti Putra Malaysia [P.U.(A) 106] 15 March 1998. The Committee recommends that the student be awarded the Master of Science.

Members of the Thesis Examination Committee were as follows:

\section{Mohd Khair bin Hassan, PhD}

Associate Professor Ir.

Faculty of Engineering

Universiti Putra Malaysia

(Chairman)

Asnor Juraiza binti Dato Hj. Ishak, PhD

Senior Lecturer

Faculty of Engineering

Universiti Putra Malaysia

(Internal Examiner)

\section{Rubiyah Yusof, PhD}

Associate Professor

Universiti Teknologi Malaysia

Malaysia

(External Examiner)

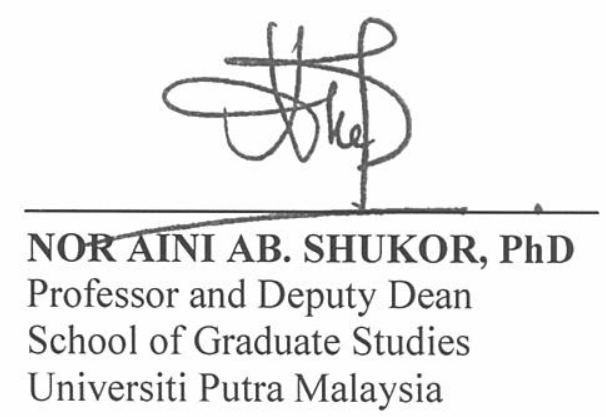

Date: 22 November 2016 
This thesis was submitted to the Senate of the Universiti Putra Malaysia and has been accepted as fulfillment of the requirement for the degree of Master of Science. The members of the Supervisory Committee were as follows:

Raja Mohd Kamil b. Raja Ahmad, PhD

Associate Professor

Faculty of Engineering

Universiti Putra Malaysia

(Chairman)

Samsul Bahari b. Mohd. Noor, PhD

Associate Professor

Faculty of Engineering

Universiti Putra Malaysia

(Internal Member)

BUJANG BIN KIM HUAT, PhD

Professor and Dean

School of Graduate Studies

Universiti Putra Malaysia

Date: 


\section{Declaration by graduate student}

I hereby confirm that:

- this thesis is my original work;

- quotations, illustrations and citations have been duly referenced;

- this thesis has not been submitted previously or concurrently for any other degree at any institutions;

- intellectual property from the thesis and copyright of thesis are fully-owned by Universiti Putra Malaysia, as according to the Universiti Putra Malaysia (Research) Rules 2012;

- written permission must be obtained from supervisor and the office of Deputy Vice-Chancellor (Research and innovation) before thesis is published (in the form of written, printed or in electronic form) including books, journals, modules, proceedings, popular writings, seminar papers, manuscripts, posters, reports, lecture notes, learning modules or any other materials as stated in the Universiti Putra Malaysia (Research) Rules 2012;

- there is no plagiarism or data falsification/fabrication in the thesis, and scholarly integrity is upheld as according to the Universiti Putra Malaysia (Graduate Studies) Rules 2003 (Revision 2012-2013) and the Universiti Putra Malaysia (Research) Rules 2012. The thesis has undergone plagiarism detection software

Signature:

Date:

Name and Matric No.: Radik Srazhidinov / GS 43480 


\section{Declaration by Members of Supervisory Committee}

This is to confirm that:

- $\quad$ the research conducted and the writing of this thesis was under our supervision;

- $\quad$ supervision responsibilities as stated in the Universiti Putra Malaysia (Graduate Studies) Rules 2003 (Revision 2012-2013) were adhered to.

Signature:

Name of Chairman

of Supervisory

Committee:

Associate Professor Dr. Raja Mohd Kamil b. Raja Ahmad

Signature:

Name of Member

of Supervisory

Committee:

Associate Professor Dr. Samsul Bahari b. Mohd. Noor 
ABSTRACT

ABSTRAK

ACKNOWLEDGEMENTS

APPROVAL

DECLARATION

LIST OF TABLES

LIST OF FIGURES

LIST OF ABBREVIATIONS

LIST OF SYMBOLS

\section{CHAPTER}

1

INTRODUCTION

1.1 Background

1.2 Problem statement

1.3 Aim and objectives

1.4 Research scope

1.5 Methodology

1.6 Thesis organization

2.1 Introduction

2.2 Active noise control structures

2.2.1 Feedforward control structure

2.3 Block-oriented secondary path representation 9

2.4 Nonlinearity in the active noise control 10

2.4.1 Propagation path nonlinearity 10

2.4.2 Reference noise nonlinearity 11

$\begin{array}{ll}2.4 .3 & \text { Nonlinearity in the sensors and actuators } \\ \text { Saturation }\end{array}$

$\begin{array}{lll}2.5 & \text { Saturation type nonlinearity models } & 12\end{array}$

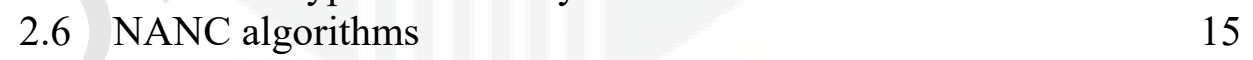

2.6.1 Volterra FXLMS (VFXLMS) 16

$\begin{array}{ll}\text { 2.6.2 Bilinear FXLMS (BFXLMS) } & 17\end{array}$

2.6.3 Leaky FXLMS (LFXLMS) 18

2.6.4 Minimum Output Variance FXLMS(MOVFXLMS) 20

2.6.5 Nonlinear FXLMS (NLFXLMS) 21

2.6.6 THF-NLFXLMS 22

$\begin{array}{lll}2.7 & \text { Summary } & 26\end{array}$

3 METHODOLOGY 27

$\begin{array}{lll}3.1 \text { Introduction } & 27\end{array}$

3.2 Wiener-Hammerstein NLFXLMS algorithm 27

3.3 Wiener-Hammerstein secondary path modelling 31

3.4 Wiener-Hammerstein THF-NLFXLMS controller design 35

$\begin{array}{lll}3.5 & \text { Summary } & 38\end{array}$ 
4.1 Introduction 39

4.2 Modelling of secondary path $\quad 39$

4.3 THF-NLFXLMS control algorithm $\quad 45$

4.4 Fulfilment of objectives $\quad 48$

4.5 Summary 49

5 CONCLUSIONS AND FUTURE WORK 50

$\begin{array}{lll}5.1 \text { Conclusions } & 50\end{array}$

5.2 Future work and study $\quad 50$

REFERENCES $\quad 52$

APPENDICES $\quad 58$

$\begin{array}{ll}\text { BIODATA OF STUDENT } & 68\end{array}$ 


\section{LIST OF TABLES}

Table

Page

$\begin{array}{lll}2.1 & \text { Smooth nonlinear function to represent saturation nonlinearity } & 14\end{array}$

2.2 The summary of the comparison between NANC algorithms [7] 25

3.1 Summary of the THF-NLFXLM algorithm 36

3.2 Complexity comparison between THF-NLFXLMS and VFXLMS 37

4.1 Estimated and true values of the secondary path $\quad 40$

4.2 Percentage of error between true $S_{i}$ and $K_{i}$ and estimated $\frac{\widehat{\beta}}{\beta} \widehat{S}_{1}$ and 44 $\frac{\widehat{\alpha}}{\alpha} \widehat{K}_{1}$ values when true nonlinearity is represented by SEF

4.3 Summary of the control results 


\section{LIST OF FIGURES}

Figure

Page

1.1 Noise level for selected urban residential areas in various states of Malaysia

$1.2 \quad$ Research Scope

2.1 A direct form discrete-time FIR filter of order $\mathrm{N}$

$2.2 \quad$ Feedforward ANC system block diagram 8

2.3 ANC secondary path components 8

2.4 Block oriented model, (a) Hammerstein model, (b) Wiener 10 model, (c) Wiener-Hammerstein model

2.5 Hard clipping function mapping 13

$\begin{array}{ll}2.6 & \text { Sigmoid function mapping }\end{array}$

2.7 SEF function with different degree of nonlinearity $\eta^{2}[4] \quad 15$

$\begin{array}{lll}2.8 & \text { FXLMS-based ANC } & 16\end{array}$

2.9 VFXLMS NANC block diagram [60] 17

2.10 BFXLMS NANC block diagram [57] 18

2.11 Feedforward structure of NANC [2] 22

2.12 Feedforward Hammerstein THF-NLFXLMS algorithm [4] 23

2.13 Feedforward Wiener THF-NLFXLMS algorithm [7] 23

3.1 Flow chart of research methodology 28

3.2 Wiener-Hammerstein ANC block diagram 29

3.3 Proposed feedforward Wiener-Hammerstein SEF-NLFXLMS 31 algorithm

3.4 Proposed modelling scheme for the Wiener-Hammerstein 32 secondary path

3.5 Proposed feedforward Wiener-Hammerstein THF-NLFXLMS algorithm 
4.1 $\alpha \mathrm{K}_{\mathrm{i}}$ (solid line) and learning curves of $\widehat{\alpha} \widehat{\mathrm{K}}_{1}$ (dashed line) for each coefficient. (a) $\widehat{\alpha} \widehat{K}_{1}$ when $\left.\eta^{2}=0.6, b\right) \widehat{\alpha} \widehat{K}_{1}$ when $\eta^{2}=1.2$, (c) $\widehat{\alpha} \widehat{K}_{1}$ when $\eta^{2}=16$

4.2 $\quad \beta \mathrm{Si}$ (solid line) and learning curves of $\beta \mathrm{Si}$ (dashed line) for each coefficient. (a) $\beta$ Si when $\eta^{2}=0.6$, (b) $\beta$ Si when $\eta^{2}=1.2$, (c) $\beta$ Si when $\eta^{2}=16$

4.3 Percentage of error between $S$ and $\frac{\widehat{\beta}}{\beta} \hat{S}$ coefficients when the true nonlinearity is represented by SEF

4.4 Percentage of error between $K$ and $\frac{\widehat{\alpha}}{\alpha} \widehat{K}$ coefficients when the true nonlinearity is represented by SEF

4.5 Mean Square Error (MSE) comparison of THF - NLFXLMS, Wiener-Hammerstein NLFXLMS and FXLMS at: (a) $\eta^{2}=0.6$ (b) $\eta^{2}=1.2$ (c) $\eta^{2}=16$

4.6 Mean Square Error (MSE) comparison of THF-NLFXLMS algorithm for Wiener and Wiener-Hammerstein structures for $\eta^{2}=0.6$. 


\section{LIST OF ABBREVIATIONS}

ADC

ANC

BFXLMS

DAC

FIR

FXLMS

IIR

LFXLMS

LMS

LNL

LTI

MOVFXLMS

MSE

NANC

NARMAX

NLFXLMS

SEF

SEF-NLFXLMS

SISO

THF

THF-NLFXLMS
Analog to Digital Converter

Active Noise Control

Bilinear Filtered-X Least Mean Square

Digital to Analog Converter

Finite Impulse Response

Filtered-X Least Mean Square

Infinite Impulse Response

Leaky Filtered-X Least Mean Square

Least Mean Square

Linear Nonlinear Linear

Linear Time Invariant

Minimum Output Variance Filtered-x Least Mean Square

Mean Square Error

Nonlinear Active Noise Control

Nonlinear Autoregressive moving models with exogenous inputs

Nonlinear Filtered-X Least Mean Square

Scaled Error Function

Scaled Error Function based Nonlinear Filtered-X Least Mean Square

Single Input Single Output

Tangential Hyperbolic Function

Tangential Hyperbolic Function based Nonlinear Filtered-X Least Mean Square

Volterra Filtered-X Least Mean Square 
VLFXLMS

VMOVFXLMS
Variable Leaky Filtered-X Least Mean Square

Variable Minimum Output Variance Filtered-X Least Mean Square 


\section{LIST OF SYMBOLS}

$\% e$

$f_{T H F}[\cdot]$

$\hat{f}_{T H F}[\cdot]$

$\widehat{\alpha}_{0}$

$\hat{\beta}_{0}$

$h_{i}$

$A_{i}(n)$

$B_{2 n}$

$B_{i}(n)$

$C_{i}(n)$

$P_{v}$

$\hat{S}(n)$

$\widehat{K}(n)$

$d \hat{f}_{\text {THF }}[\cdot]$

$\hat{d}(n)$

$e_{n l}(n)$

$f^{\prime}[\cdot]$

$f_{S E F}[\cdot]$

$x_{f}(n)$

$\gamma_{0}$

$\eta^{2}$

$\nabla J(n)$
Percentage of the approximation error

Tangential hyperbolic function

Estimated tangential hyperbolic function

Initial value of $\hat{\alpha}$

Initial value of $\hat{\beta}$

Coefficient of the Volterra filter

Coefficients of the Bilinear filter delayed input

Even index Bernoulli number

Coefficients of the delayed output

Coefficients of the Bilinear filter delayed input-output cross multiplied sample

Order of the Volterra filter

First estimated secondary path

Second estimated secondary path

Derivative of the estimated tangential hyperbolic function

Estimated primary noise signal at the observer

Nonlinear error

Derivative of the nonlinear function

Scaled error function

Filtered reference signal

Optimum leakage factor

Degree of nonlinearity in SEF function

Convolution operator

Derivative of the cost function 


\begin{tabular}{|c|c|}
\hline$H(n)$ & The matrix of the Volterra coefficient \\
\hline$J(n)$ & Cost function \\
\hline$L$ & Length of FIR filter ( $1^{\text {st }}$ secondary path) \\
\hline$M$ & Length of FIR filter ( $2^{\text {nd }}$ secondary path) \\
\hline$N$ & Number of samples \\
\hline$P(n)$ & Primary path \\
\hline$S(n)$ & First secondary path \\
\hline$K(n)$ & Second secondary path \\
\hline$W(n)$ & Controller \\
\hline$d(n)$ & Primary noise signal at the \\
\hline$e(n)$ & Linear error \\
\hline$f[\cdot]$ & Nonlinear functi \\
\hline $\operatorname{sgn}(x)$ & Sign function \\
\hline$v(n)$ & Modelling signal \\
\hline$x(n)$ & Reference signal \\
\hline$z(n)$ & Gaussian measurement noise \\
\hline$\alpha$ & Scaling parameters in THF function \\
\hline$\beta$ & Degree of nonlinearity in THF function \\
\hline$\gamma$ & Leakage factor \\
\hline$\mu$ & Step size of the adaptive algorithm \\
\hline$\xi$ & First scaling parameter of the sigmoid function \\
\hline$\vartheta$ & Second scaling parameter of the sigmoid function \\
\hline$\varrho$ & Scaling parameter of the soft clipping function \\
\hline
\end{tabular}




\section{CHAPTER 1}

\section{INTRODUCTION}

\subsection{Background}

Noise pollution has many negative effects on human health, such as: hearing loss, cardiovascular disease, mental illness and negative social behaviour [1] and [2]. Figure 1.1 shows that in most states of Malaysia the noise level exceed both day and night time limits. High frequency noise can be controlled using passive methods, for example barriers and silencers. However, this method is not effective for low frequency noise below $500 \mathrm{~Hz}$, because this low frequency noise has longer wavelength that allows the noise to penetrate through the barriers and silencers [3]. An active noise control (ANC) method is on effective method that can be used to cancel low frequency noise using the principle of superposition.

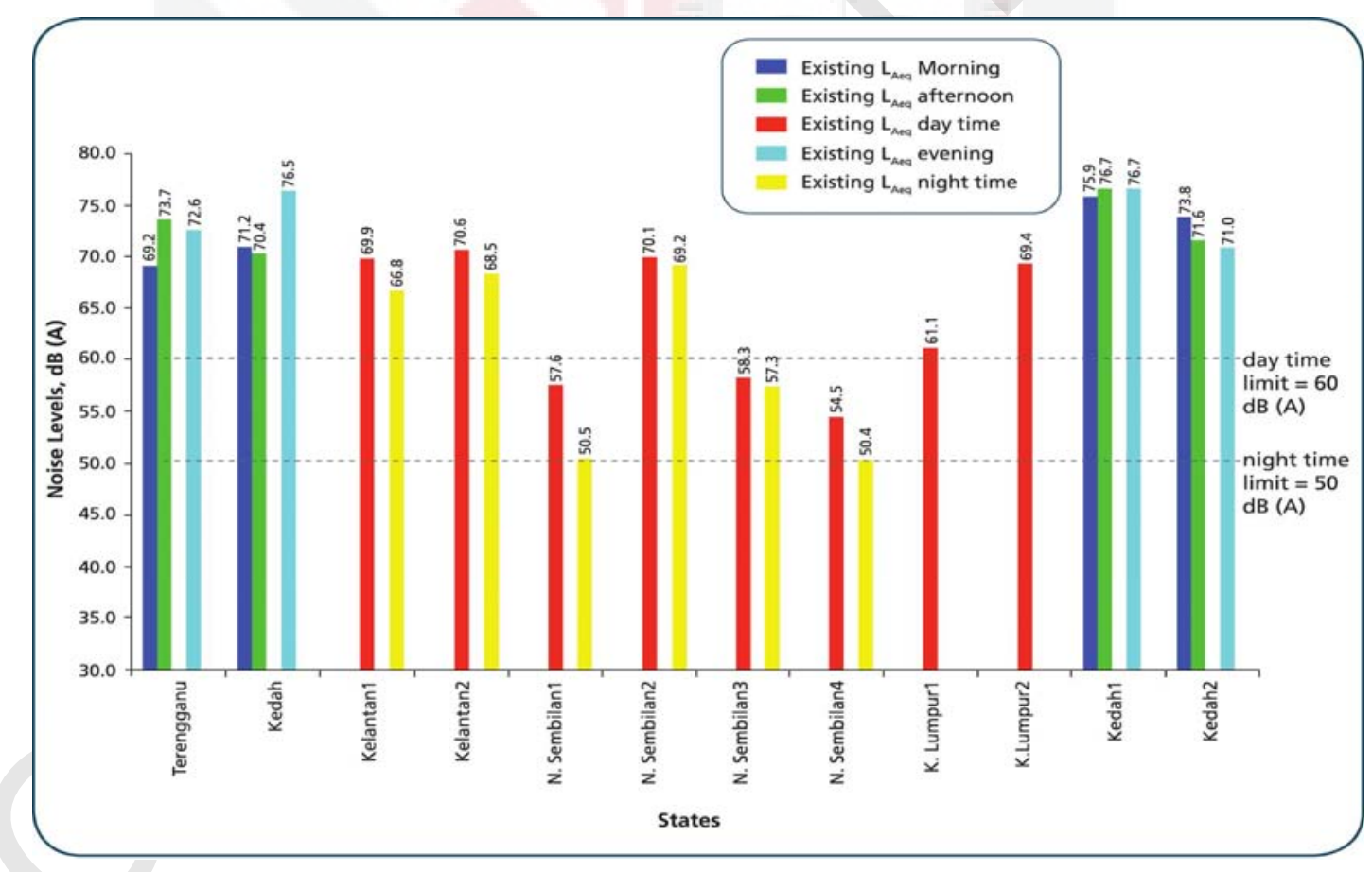

Figure 1.1 : Noise level for selected urban residential areas in various states of Malaysia

Nonlinear active noise control (NANC) is a method to cancel an unwanted noise by generating an antinoise through secondary source (loudspeaker) in the system that contains secondary path nonlinearity [1]. Adaptive control technique is widely applied to design the controller in order to overcome the nonlinearity in the NANC. The two methodologies used in designing an adaptive NANC are direct and indirect methods. For the direct method, adaptation of the controller is achieved without utilizing the nonlinear model of the secondary path. An example of direct method algorithms such 
as filtered-X least mean square (FXLMS), bilinear FXLMS (BFXLMS), Volterra FXLMS (VFXLMS), leaky FXLMS (LFXLMS) and minimum output variance (MOVFXLMS). In the indirect method, the controller is designed by utilizing the secondary path's nonlinear saturation model. Nonlinear FXLMS (NLFXLMS) is the only algorithm that fall under this method, where the scaled error function (SEF) is used to represent the nonlinear saturation model [2]. Block oriented structure is usually used to represent secondary path by separating it into linear and nonlinear blocks [3]. Three block oriented structures are used in NANC: Wiener (linear-nonlinear), Hammerstein (nonlinear-linear) and Wiener-Hammerstein (linear-nonlinear-linear). In [2] and [4], the Wiener and Hammerstein NLFXLMS algorithms were proposed. These algorithms have the best performance in NANC system and low computational complexity. The application of NLFXLMS algorithm for Wiener-Hammerstein block oriented structure is yet to be developed and becomes the subject of this research.

The secondary path in ANC consists of D/A and A/D converters, amplifier, actuators, sensors and acoustic path [5]. In practice, one of these components may be nonlinear. Wiener-Hammerstein block oriented structure can be used when the nonlinear component exists between two linear filters. For instance, a nonlinear loudspeaker is sandwiched between linear amplifier and linear acoustic path [5].

Nonlinearity in secondary path is commonly represented by saturation nonlinearity and the clipping effect is represented using SEF [6]. The major drawback of using SEF based NLFXLMS (SEF-NLFXLMS) is the requirement of prior knowledge about the system's nonlinearity degree. In the work [4] and [7], the SEF was approximated by using tangential hyperbolic function (THF) for Wiener and Hammerstein NLFXLMS algorithms. It was shown that THF can model SEF with certain level of accuracy. Least mean square (LMS) algorithm is used to model the nonlinearity block represented by THF and this information can be used in THF based NLFXLMS (THFNLFXLMS) algorithm control design.

\section{2}

\section{Problem Statement}

SEF-NLFXLMS gives the highest results of noise cancellation. It is used as a benchmark in performance comparison since SEF-NLFXLMS utilizes the true value of the nonlinearity degree which is represented by saturation model [4]. This saturation nonlinearity in NLFXLMS algorithm is usually modelled by SEF [2]. The algorithm is limited in practical application due to the requirement of prior information about the nonlinearity degree that is usually assumed to be known [4] and [7]. This limitation leads to the development of the THF-NLFXLMS algorithm where the nonlinearity degree is estimated by modelling the secondary path. The most general and complete representation of block oriented NANC structure is the Wiener-Hammerstein model. Wiener-Hammerstein structure has advantage over Hammerstein and Wiener structure because it includes acoustic path into modelling rather than assuming that it is a unit gain. It is hypothesized that modelling the acoustic secondary path would improve the level of noise cancellation. However, SEF-NLFXLMS and the improved THFNLFXLMS algorithms have not yet been developed for this structure and are addressed in this research. 


\subsection{Aims and Objectives}

The aim of this research is to develop a methodology for modelling the nonlinearity in Wiener-Hammerstein secondary path structure and use this model to design an active noise controller based on THF-NLFXLMS algorithm. The proposed algorithm must have comparable performance with the benchmark SEF-NLFXLMS in terms of level of noise cancellation. The following objectives have been outlined in order to achieve the aims of the research:

1. To develop benchmark SEF-NLFXLMS algorithm for Wiener-Hammerstein structure.

2. To develop a methodology for modelling the nonlinearity in WienerHammerstein secondary path structure and use this model to design THFNLFXLMS algorithm.

3. To compare the performance of SEF-NLFXLMS and THF-NLFXLMS with FXLMS and $2^{\text {nd }}$ order VFXLMS algorithms.

\section{$1.4 \quad$ Research Scope}

The work is restricted to single-input single-output (SISO) feedforward ANC system. The feedforward strategy is used to control the noise at the observer. All the transfer function and filters, including reference signal and primary path, are assumed to be linear except the nonlinear block in secondary path which is represented by a memoryless saturation nonlinearity. This work involves designing and simulating the proposed modelling and control techniques. At the control stage, an alternative THFNLFXLMS algorithm is proposed and compared with NLFXLMS, FXLMS and $2^{\text {nd }}$ order Volterra algorithms with similar complexity. Figure 1.2 illustrates the research scope which is covered in this simulation. 


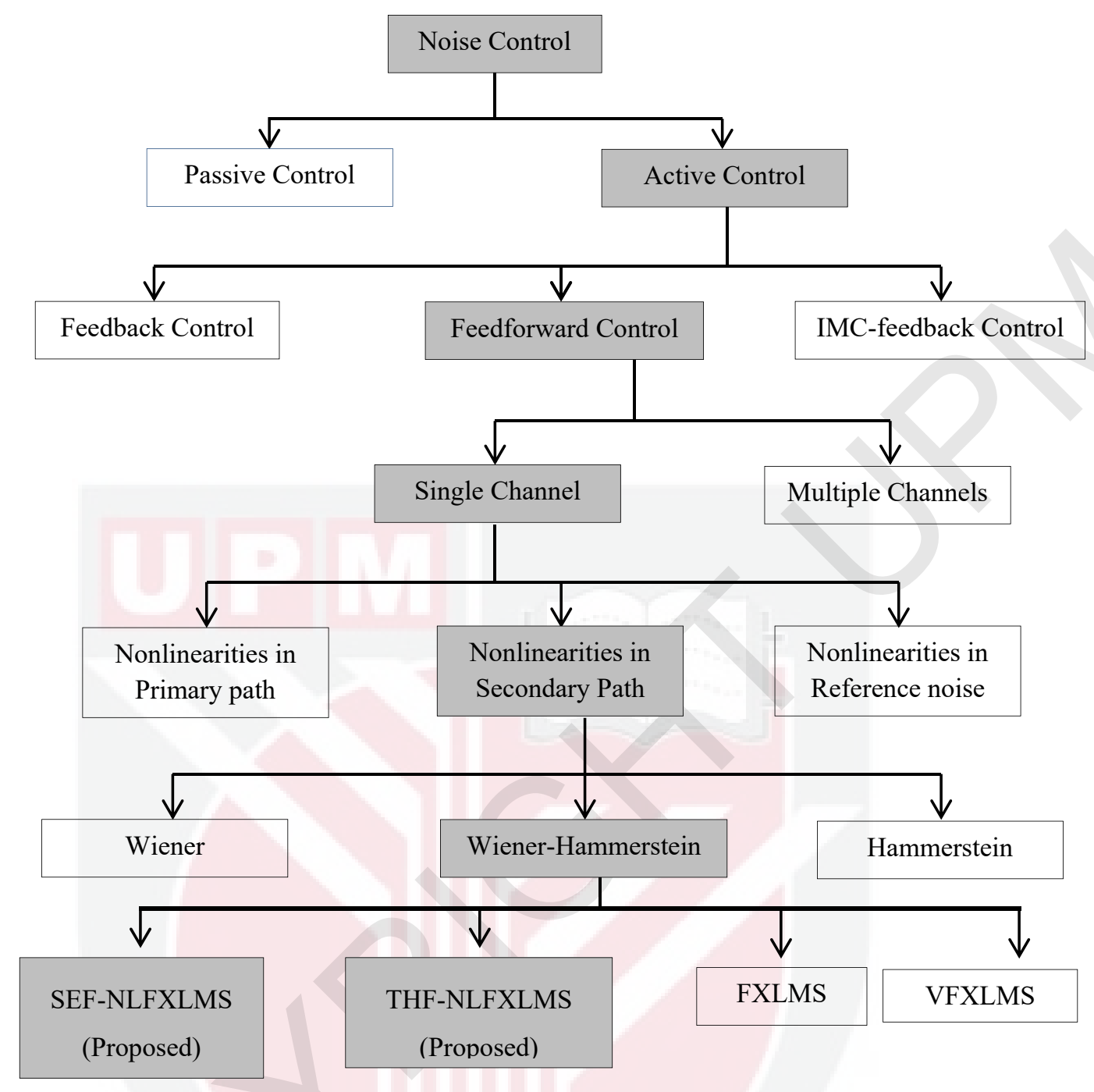

Figure 1.2 : Research scope

\subsection{Methodology}

The methodology of this research has three substantial parts: development of SEFNLFXLMS control algorithm, secondary path modelling, and THF-NLFXLMS control algorithm. Firstly, the SEF-NLFXLMS algorithm is developed for WienerHammerstein block oriented structure. Then, the secondary path is modelled with saturation nonlinearity that is estimated using THF.

To overcome the drawback of SEF-NLFXLMS where the nonlinearity degree must be known in advance, the proposed secondary path model was used to design THFNLFXLMS algorithm. This proposed control algorithm is compared with SEFNLFXLMS, FXLMS and $2^{\text {nd }}$ order Volterra FXLMS (with similar computational complexity as THF-NLFXLMS) using Mean Square Error (MSE) criterion. 


\subsection{Thesis Organization}

This thesis is organized into five chapters. Chapter 1 presents the introduction, research problems, research objectives, research aim and methodology of the study. Chapter 2 presents the literature review related to the algorithms of NANC systems. Nonlinearities in the secondary path and their mathematical representations are discussed. Block oriented structure of nonlinear secondary path are provided in this section. In Chapter 3, the SEF-NLFXLMS and THF-NLFXLMS algorithms are developed and derived for NANC with nonlinearities in secondary path with WienerHammerstein structure. The secondary path modelling is proposed to estimate the secondary path linear and nonlinear values. In chapter 4 , the numerical simulation is performed for the proposed secondary path modelling and control, the THF-NLFXLM algorithm is compared with SEF-NLFXLM, FXLMS and $2^{\text {nd }}$ order VFXLMS algorithms. Finally, in Chapter 5 the conclusion is provided with possible future perspectives of the work. 


\section{REFERENCES}

[1] George N. V., and Panda G., "A particle-swarm-optimization-based decentralized nonlinear active noise control system," IEEE Trans. Instrum. Meas., vol. 61, no. 12, pp. 3378-3386, 2012.

[2] Tobias O. and Seara R., "Performance comparison of the FXLMS, nonlinear FXLMS and leaky FXLMS algorithms in nonlinear active control applications," in Proc. European Signal Processing Conference, vol. 1, no. 2, pp. 2-5, 2002.

[3] Zhou D. and DeBrunner V., "Efficient Adaptive Nonlinear Filters for Nonlinear Active Noise Control," IEEE Trans. Circuits Syst. I Regul. Pap., vol. 54, no. 3, pp. 669-681, 2007.

[4] Sahib M. A., Kamil R., and Marhaban M. H., "Nonlinear FXLMS algorithm for active noise control systems with saturation nonlinearity," IEEJ Trans. Electr. Electron. Eng., vol. 7, no. 6, pp. 598-606, 2012.

[5] Hegde V., Radhakrishnan C., Krusienski D., and Jenkins W. K., "SeriesCascade Nonlinear Adaptive Filters," in The 2002 45th Midwest Symposium on Circuits and Systems, 2002. MWSCAS-2002., no. c, pp. 219-222, 2002.

[6] Costa M. H., Bermudez J. C. M., and Bershad N. J., "Stochastic analysis of the LMS algorithm with a saturation nonlinearity following the adaptive filter output," IEEE Trans. Signal Process., vol. 49, no. 7, pp. 1370-1387, 2001.

[7] Ghasemi S., Kamil R., and Marhaban M. H., "Nonlinear Thf-Fxlms Algorithm For Active Noise Control With Loudspeaker Nonlinearity," Asian J. Control, vol. 18, no. 3, p. 1-12, 2015.

[8] Bambang R. T., Yacoub R., and Hertanza R., "Recent Progress in Adaptive Nonlinear Active Noise Control," International Conference on Electrical Engineering and Informatics,Indonesia, pp. 1-7, 2011.

[9] Hansen C. H., Active control of noise and vibration. CRC Press, 2013.

[10] Bies D. A. and Hansen C. H., Engineering noise control: theory and practice: CRC Press, 2009.

[11] Kajikawa Y., Gan W. S., and Kuo S. M., "Recent applications and challenges on active noise control," APSIPA Transactions on Signal and Information Processing, vol. 1, 2012, e3, doi:10.1017/ATSIP.2012.4.

[12] Kuo S. M. and Morgan D. R., "Review of DSP algorithms for active noise control," Proc. 2000. IEEE Int. Conf. Control Appl. Conf. Proc. (Cat. No.00CH37162), pp. 243-248, 2000. 
[13] Kuo S. M. and Morgan D. R., "Active noise control: a tutorial review," Proc. IEEE, vol. 87, no. 6, pp. 943-973, 1999.

[14] Elliott S., Signal processing for active control. Academic press, 2000.

[15] Abraham R. S. and Veena S., "Active Noise Control Using IIR Adaptive Filter," no. 6, pp. 55-58, 2012.

[16] Elliott S. J. and Sutton T. J., "Performance of feedforward and feedback systems for active control," IEEE Trans. Speech Audio Process., vol. 4, no. 3, pp. 214-223, 1996.

[17] Sakai H. and Miyagi S., "Analysis of the adaptive filter algorithm for feedbacktype active noise control," Signal Processing, vol. 83, pp. 1291-1298, 2003.

[18] Nakrani N. and Patel N., "Feed-Forward and Feedback Active Noise Control System Using FxLMS Algorithm for Narrowband and Broadband Noise," 2012 Int. Conf. Commun. Syst. Netw. Technol., no. 1, pp. 577-580, 2012.

[19] Ardekani I. T. and Abdulla W. H., "FxLMS-based active noise control: A quick review," Proc., vol. 1, pp. 1-11, 2011.

[20] Zangi K. C., "Optimal Feedback Control Formulation of the Active Noise Cancellation Problem : Pointwise and Distributed," no. 583, pp. 1-158, 1994.

[21] Astrom K. J. and Murray R. M., Feedback Systems: An Introduction for Scientists and Engineers. Princeton University Press, 2009.

[22] Ogunfunmi T., Adaptive Nonlinear System Identification: The Volterra and Wiener Model Approaches. Signals and Communication Technology. Springer, 2007.

[23] Bambang R. T., "Adjoint EKF learning in recurrent neural networks for nonlinear active noise control," Applied Soft Computing, vol. 8, pp. 1498-1504, 2008.

[24] Behera S. K., Das D. P. and B. Subudhi, "Functional link artificial neural network applied to active noise control of a mixture of tonal and chaotic noise," Applied Soft Computing, vol. 23, pp. 51-60, 2014.

[25] Bendat J. S., Nonlinear system techniques and applications: John Wiley \& Sons, Inc., 1998.

[26] Sankar D. and Thomas T., "Nonlinear modeling of loudspeaker using adaptive second order Volterra filters," in Proc. IEEE Int. Conf. on Information and Communication Technology in Electrical Sciences (ICTES), 2007, pp.87-92.

[27] Isaksson M., Wisell D. and Ronnow D., "A comparative analysis of behavioral models for RF power amplifiers," IEEE Trans. on Microwave Theory and Techniques, vol. 54, pp. 348-359, 2006. 
[28] Bershad N. J., Bouchired S., and Castanie F., "Stochastic analysis of adaptive gradient identification of Wiener-Hammerstein Systems for Gaussian inputs," IEEE Trans. Signal Process., vol. 48, no. 2, pp. 557-560, 2000.

[29] Giri F. and Bai E. W., Block-oriented nonlinear system identification: Springer, 2010.

[30] Dreesen P., Schoukens M., Tiels K., and Schoukens J., "Decoupling Static Nonlinearities in a Parallel Wiener-Hammerstein System: A First-order Approach," IEEE International Instrumentation and Measureent Technology Conference, pp.987-992, 2015.

[31] Mazur K. and Pawełczyk M., "Hammerstein Nonlinear Active Noise Control with the Filtered-Error LMS Algorithm," Arch. Acoust., vol. 38, no. 2, pp. 197-203, 2013.

[32] Klippel W., "Active attenuation of nonlinear sound," US Patent: 6,005,952, 1999.

[33] Reddy E. P., Das D. P. and Prabhu K., "Fast exact multichannel FSLMS algorithm for active noise control," Signal Processing, vol. 89, pp. 952-956, 2009.

[34] Strauch P. and Mulgrew B., "Active control of nonlinear noise processes in a linear duct," IEEE Trans. on Signal Processing, vol. 46, pp. 2404-2412, 1998.

[35] Kim I. S., Na H. S., Kim K. J., and Park Y., "Constraint filtered-x and filteredu least-mean-square algorithms for the active control of noise in ducts," $J$. Acoust. Soc. Am., vol. 95, no. 6, pp. 3379-3389, 1994.

[36] Behera S. B., Das D. P. and Rout N. K., "Nonlinear feedback active noise control for broadband chaotic noise," Applied Soft Computing, vol. 15, pp. 80$87,2014$.

[37] Tarchi D., Lukin K., Fortuny-Guasch J., Mogyla A., Vyplavin P. and Sieber A., "SAR imaging with noise radar," IEEE Trans. on Aerospace and Electronic Systems, vol. 46, pp. 1214-1225, 2010.

[38] Li Z., Dong H. and Quan T., "Apply genetic algorithm to parameter estimation in chaotic noise," in Proc. IEEE Int. Conf. on Signal Processing, 2002, pp. 1399-1402.

[39] Russo F. and Sicuranza G. L., "Accuracy and performance evaluation in the genetic optimization of nonlinear systems for active noise control," IEEE Trans. on Instrumentation and Measurement, vol. 56, pp. 1443-1450, 2007.

[40] Zhao H. and Zhang J., "Filtered-s Lyapunov algorithm for active control of nonlinear noise processes," in Proc. IEEE Int. Conf. on Signal Processing (ICSP), 2008, pp. 311-314. 
[41] Sicuranza G. L. and Carini A., "On the accuracy of generalized Hammerstein models for nonlinear active noise control," in Proc. IEEE Int. Conf. Instrumentation and Measurement Technology (IMTC), 2006, pp. 1411-1416.

[42] Das D. P. and Panda G., "Active mitigation of nonlinear noise processes using a novel filtered-s LMS algorithm," IEEE Trans. on Speech and Audio Processing, vol. 12, pp. 313-322, 2004.

[43] Sprott J. C. and Sprott J. C., Chaos and time-series analysis: Oxford University Press, 2003.

[44] Kuo S. M. and Wu H. T., "Active noise control systems with adaptive nonlinear filters," in Proc. IEEE Int. Conf. on Control Applications, 2004, pp. $1330-1335$.

[45] Kuo S. M., Wu H. T., Chen F. K. and Gunnala M. R., "Saturation effects in active noise control systems," IEEE Trans. on Circuits and Systems I: Regular Papers, vol. 51, pp. 1163-1171, 2004.

[46] Stenger A. and Kellermann W., "Adaptation of a memoryless preprocessor for nonlinear acoustic echo cancelling," Signal Processing, vol. 80, pp. 17471760, 2000.

[47] Costa M. H. and Bermudez J. C. M., "A new adaptive algorithm for reducing non-linear effects from saturation in active noise control systems," International Journal of Adaptive Control and Signal Processing, vol. 19, pp. 177-196, 2005.

[48] Tobias O. J. and Seara R., "Leaky-FXLMS algorithm: stochastic analysis for Gaussian data and secondary path modeling error," IEEE Trans on. Speech and Audio Processing, vol. 13, pp. 1217-1230, 2005.

[49] Gontijo W. A., Tobias O. J., Seara R. and Lopes E. M., "FxLMS algorithm with variable step size and variable leakage factor for active vibration control," in Proc. IEEE Int. Conf. on Telecommunications Symposium, 2006, pp. 572575.

[50] Tobias O. J. and Seara R., "On the LMS algorithm with constant and variable leakage factor in a nonlinear environment," IEEE Trans. on Signal Processing, vol. 54, pp. 3448-3458, 2006.

[51] Tan L. and Jiang J., "Adaptive Volterra filters for active control of nonlinear noise processes," IEEE Trans. on Signal Processing, vol. 49, pp. 1667-1676, 2001.

[52] Tan L. and Jiang J., "Adaptive second-order volterra filtered-X RLS algorithms with sequential and partial updates for nonlinear active noise control," in Proc. IEEE Int. Conf. on Industrial Electronics and Applications (ICIEA), 2009, pp. 1625-1630. 
[53] Bouchard M., Paillard B. and Le Dinh C. T., "Improved training of neural networks for the nonlinear active control of sound and vibration," IEEE Trans. on Neural Networks, vol. 10, pp. 391-401, 1999.

[54] Bouchard M., "New Recursive-Least-Squares Algorithms for Nonlinear Active Control of Sound and Vibration Using Neural Networks," IEEE Trans. Neural Netw., vol. 12, no. 1, pp. 135-147, 2001.

[55] Kuo S. M. and Wu H.-T., "Nonlinear adaptive bilinear filters for active noise control systems," IEEE Trans. on Circuits and Systems I: Regular Papers, vol. 52, pp. 617-624, 2005.

[56] Napoli R. and Piroddi L., "Nonlinear Active Noise Control Using NARX Model Structure Selection,” Control, pp. 5616-5621, 2009.

[57] Sicuranza G. L. and Carini A., "Filtered-X affine projection algorithm for multichannel active noise control using second-order Volterra filters," IEEE Signal Processing Letters, vol. 11, pp. 853-857, 2004.

[58] Sahib M. A. and Kamil R., "Comparison of Performance and Computational Complexity of Nonlinear Active Noise Control Algorithms," ISRN Mech. Eng., vol. 2011, pp. 1-9, 2011.

[59] Piroddi L. and Spinelli W., "An identification algorithm for polynomial NARX models based on simulation error minimization," International Journal of Control, vol. 76, pp. 1767-1781, 2003.

[60] Kuo S. M. and Morgan D., Active noise control systems: algorithms and DSP implementations: John Wiley \& Sons, Inc., 1995.

[61] David A. C, Laura R. R, and Robert D. C, "Lyapunov Tuning Of The Leaky Lms Algorithm For Singlesource, Single-Point Noise Cancellation" Proceedings of the American Control Conference, pp. 3600-3605, 2003.

[62] Bermudez J. and Costa M. H., "Optimum leakage factor for the MOV-LMS algorithm in nonlinear modeling and control systems," in Proc. IEEE Int. Conf. on Acoustics, Speech, and Signal Processing (ICASSP), 2002, pp. 1393-1396.

[63] Costa M. H. and Bermudez J. C., "A true stochastic gradient adaptive algorithm for applications using nonlinear actuators," in Proc. IEEE Int. Conf. on Acoustics, Speech, and Signal Processing (ICASSP), 2001, pp. 3489-3492.

[64] Chang D. C. and Chu F. T., "Active noise cancellation with a new variable tap length and step size FXLMS algorithm," Proc. - IEEE Int. Conf. Multimed. Expo, 2013.

[65] Kibangou A. Y. and Favier G., "Wiener-Hammerstein systems modeling using diagonal Volterra kernels coefficients," IEEE Signal Process. Lett., vol. 13, no. 6, pp. 381-384, 2006. 
[66] Huang B., Xiao Y., Sun J., and Wei G., "A variable step-size FXLMS algorithm for narrowband active noise control," IEEE Trans. Audio, Speech Lang. Process., vol. 21, no. 2, pp. 301-312, 2013. 